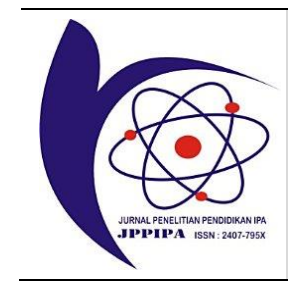

\title{
Development of Discovery Learning Student Worksheets to Improve Students' Critical Thinking Skills in Chemical Balance Materials
}

\author{
Ainur Rizki1 ${ }^{*}$, Ibnu Khaldun², Andi Ulfa Tenri Pada ${ }^{3}$ \\ ${ }^{1}$ Science Education Study Program, PPs, Syiah Kuala University, Banda Aceh, Indonesia \\ ${ }^{2}$ Chemistry Education Study Program, FKIP, Syiah Kuala University, Banda Aceh, Indonesia \\ ${ }^{3}$ Biology Education Study Program, FKIP, Syiah Kuala University, Banda Aceh, Indonesia
}

DOI: $\underline{10.29303 / j p p i p a . v 7 i 4.829}$

\section{Article Info}

Received: June $5^{\text {th }}, 2021$

Revised: September $25^{\text {th }}, 2021$

Accepted: October 13th, 2021

\begin{abstract}
This study aims to determine the quality of Discovery Learning Student Worksheets to improve students' critical thinking skills and increase students' Critical Thinking Skills on chemical equilibrium material. This study uses research development methods with the design of the Borg and Gall models. The samples in this study were 140 students of Al-Falah Islamic Senior High School Aceh Besar to develop Student Worksheets and 61 people of IT Al-Fitiyan Senior High School to implement Discovery Learning Student Worksheets. The instruments used were questions and student response questionnaires. The data analysis technique uses the percentage equation and analysis of students' critical thinking skills improvement using the N-gain equation and independentsample t-test. The results showed that the quality of the Discovery Learning Student Worksheets could improve students' critical thinking skills on chemical equilibrium material, as evidenced by the results of the quality assessment of the Discovery Learning Student Worksheets from the validation results obtained an average of $79 \%$ with a decent category. The analysis of students' critical thinking skills proves that there is a difference in the average critical thinking skills of students before and after applying the Discovery Learning Student Worksheet on chemical equilibrium material with a Sig value. (2-tailed) < 0.05. The results obtained prove that the use of Discovery Learning Student Worksheets is better than conventional Student Worksheets in improving students' Critical Thinking Skills.
\end{abstract}

Keywords: Student Worksheets; Discovery Learning; Critical Thinking Skills

Citation: Rizki, A., Khaldun, I., \& Pada, A.U.T. (2021). Dedevelopment of Discovery Learning Student Worksheets to Improve Students' Critical Thinking Skills in Chemical Balance Materials. Jurnal Penelitian Pendidikan IPA, 7(4), 707-711. doi:https://doi.org/10.29303/jppipa.v7i4.829

\section{Introduction}

Chemistry learning in Aceh Besar district is currently known to be still not optimal. This is evidenced from the chemistry national exam data for the last three years from 2016/2017, 2017/2018 to 2018/2019 academic years, namely 43.65, 40.47, and 45.05. Based on national exam data for the 2018/2019 academic year, it is known that chemical equilibrium is one of the chemistry learning materials, which is still relatively low, with an average value of 20.53. This achievement is relatively low when compared to the national value, which is around 31.54 (Puspendik,
2019). The influence of learning outcomes can cause the low value of the national exam.

Based on observations that have been made on July 16, 2019, at Al-Falah Islamic Senior High School Aceh Besar, the activities of students during teaching and learning still look less active. The learning process still tends to be centered on the teacher while students only listen and record what the teacher says so that the interaction still looks passive. The observations also show that the daily test scores of students on the chemical equilibrium material for the 2018/2019 academic year even semester are still low compared to the minimum completeness criteria for the subjects, 
which is 65 . The students' daily test passing rate is based on the minimum completeness criteria values ranging from $48 \%$ so that they can conclude that students' learning outcomes on this material are not optimal. An alternative that teachers can use to improve learning outcomes is to develop students' critical thinking skills. Amijaya et al. (2018) stated that Critical Thinking Skills could improve student learning outcomes. Critical Thinking Skills can be applied with the help of appropriate learning models, one of which is discovery learning.

Discovery Learning learning model is one of the learning references that does not only explore theoretical subject matter but also proves concepts through discovery and develops students' thinking skills to be skilled, independent, able to find new concepts and relate them to what has been learned and improve understanding through the scientific method (Donuk, 2016). The Discovery Learning model effectively increases active learning because it can integrate new information obtained until they find the right knowledge (Rahman \& Hi, 2017).

Based on research conducted by Farid (2018) that learning using the Discovery Learning model can improve student learning outcomes. The Discovery Learning Model Nugrahaeni et al. (2017) mentioned that there was an increase in student learning outcomes after the Discovery Learning learning model was applied. In the development of discovery learningbased Student Worksheets, participants are not given initial information first, so that students who find the information are based on the instructions contained in the Student Worksheet, which aims to find an answer to a problem that they do not know (Ariani \& Meutiawati, 2010, 2020). The Student Worksheet which is commonly used by chemistry teachers at Al-Falah Islamic Senior High School only contains material and questions so that it does not support students' critical thinking skills. Therefore, a Discovery Learning Student Worksheet will be developed which is expected to improve students' critical thinking skills.

The results of previous studies prove that the use of Student Worksheets with discovery learning models can improve critical thinking skills because Student Worksheets are interesting learning media, making students active in participating in the learning process and working together in groups (Rahayuningsari et al., 2020). Discovery learning is learning that emphasizes direct experience, and students organize the learning materials they learn in a final form that is in accordance with the level of progress of students' thinking without having to always rely on learning theories in textbooks (Fadila \& Taufik, 2020).

The Discovery Learning learning model is a learning model that provides opportunities for students to build their own understanding (Qurniati et al., 2015). Based on several advantages of the discovery learning model, to improve students' understanding of the chemical concept of chemical equilibrium material, the Discovery Learning Student Worksheet is considered suitable as a teaching material that plays an important role in improving students' $\mathrm{CBC}$.

\section{Method}

This study uses research and development methods. Needs analysis is carried out using survey or qualitative methods that are very necessary to produce the products needed appropriately so that it will be useful for the wider community in particular. The product produced in this study is the Discovery Learning Student Worksheet. The research design used the Borg and Gall model. The stages are (1) research and initial data collection; (2) planning; (3) initial product development; (4) initial trial; (5) product revision for the main product; (6) field trials (I); (7) product revision to prepare operational products; (8) field trials (II) of the revised product; (9) final product revision; and (10) product implementation (Borg and Gall, 1989).

The types of research conducted in this study are quantitative and qualitative. The combination of quantitative and qualitative research is used so that researchers obtain complete, valid, reliable, and objective data and information. The population in this study were all students of class XI MIA at two Senior High schools in Aceh Beser. There are 180 MIA students in Alfalah Senior High School from 6 classes and 90 students in class XI MIA at It Al-Fitiyan Senior High School from three classes for the 2020/2021 school year. Sampling was carried out by purposive sampling, namely in the form of a sample target based on the equation of the low percentage of national exam scores in chemistry lessons on chemical equilibrium material indicators at the Senior High School in Aceh Besar district. The sample in this study was the students of Islam Al-Falah Senior High School Aceh Besar as many as 140 students for the development of Student Worksheets and IT Al-Fitiyan Senior High School as many as 61 students for the implementation of the Discovery Learning Student Worksheets, which had been developed with the aim of improving thinking skills student critical. From 60 students, 31 students will be used as experimental class and 30 students in the control class.

The instruments used in this study were questions and student response questionnaires. The data collection procedures to determine students' critical thinking skills through the development of 
Discovery Learning Student Worksheets by providing pretest and posttest during the learning activities. The data analysis technique in this study was to analyze the feasibility of the Student Worksheet using the percentage equation. Next, analyze the improvement of students' critical thinking skills using the $\mathrm{N}$-gain equation and the average difference of the independent sample t-test. The prerequisite test in the independent sample t-test consists of the Kolmogorov-Smirnov normality test and the homogeneity test.

\section{Result and Discussion}

\section{Development of Discovery Learning-Based Student Worksheets}

The stages of developing the Discovery Learning Student Worksheet in this study used the ten-step Borg \& Gall model. The activity steps include; 1) collecting initial information, 2) learning planning 3) developing initial product drafts, 4) piloting initial drafts, 5) revising initial products, 6) field trials I, 7) revising products, 8) field trials II, 9) Revising the final product, and 10) mass production or product implementation.

\section{Gather initial information}

The process of developing the Student Worksheet in the early stages is collecting initial information. Information collection is carried out through observation activities to schools to find out learning problems. Based on the information obtained that teaching materials so far have only been based on textbooks, but the use of student worksheets does not apply the steps of an interesting learning model, so there are still some students who do not think critically, creatively, and lack independence in learning.

The lack of use of Student Worksheets in schools is one of the obstacles faced by students in their ability to understand scientific theories or concepts clearly. The Student Worksheet's function and purpose are to make it easier for students to understand a concept or material, activate it in the learning process, train to find and develop process skills, and guide the learning process. According to Diani et al. (2019), The Student Worksheet is a sheet containing questions that direct students to understand the concepts contained in the material so that it is easier for students to write important concepts in mind mapping.

\section{Lesson planning}

Based on the results of previous observations, one of the learning resources that must be developed to assist and facilitate teaching and learning activities is to form effective interactions between students and educators and increase student activity through the application of Student Worksheets. The purpose of the planning stage is to design student worksheet formats for learning. Student Worksheet Development aims to develop new student activity sheets or improve existing ones. When designing Student Worksheets, it is necessary to pay attention to several factors, namely the level of students' reading ability and students' knowledge. Students are expected to be able to learn independently with the Student Worksheet that the teacher has designed. The teacher becomes a facilitator when students play an active role in learning the material.

According to Lestari et al. (2019), to produce innovative and creative Student Worksheets, it is necessary to pay attention to the steps in preparing a good Student Worksheet. The steps for preparing the Student Worksheet are: (a) conducting curriculum analysis; (b) compiling a map of Student Worksheet needs (c) determining the title of the Student Worksheet and (d) writing the Student Worksheet Zammiluni et al. (2018) said that the Student Worksheet is a learning component that is based on the 2013 curriculum, so the use of the Student Worksheet will not give satisfactory results without using a learning model in learning activities. This Student Worksheet consists of an introduction in the form of concepts related to project assignments, questions related to science concepts, modifications to be carried out, work procedures (students are asked to carry out practical activities according to the Discovery Learning steps.

\section{Early product draft development}

The design of developing the structure of the Student Worksheet is adjusted to the structure of the Student Worksheet according to the Ministry of National Education (2006), namely a good structure that includes titles, study instructions, competencies achieved, supporting information, tasks, and work steps. Some of the product drafts of discovery learningbased Student Worksheets can be seen below.

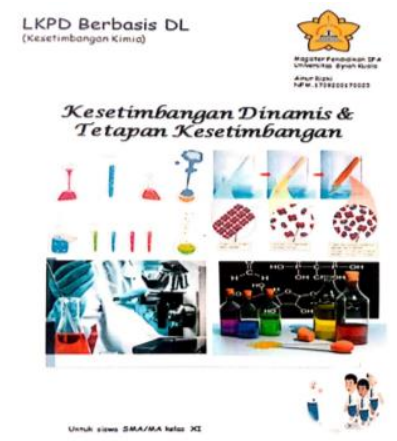

(a)

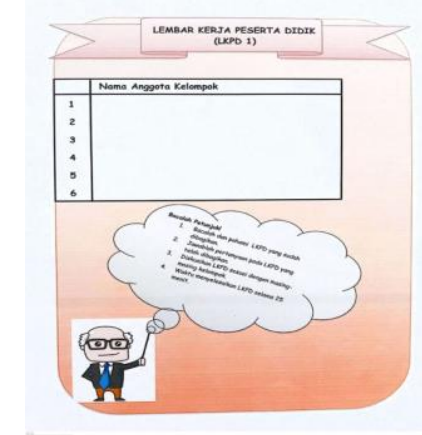

(b) 


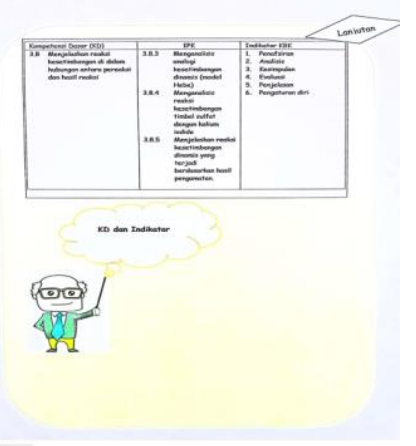

(c)

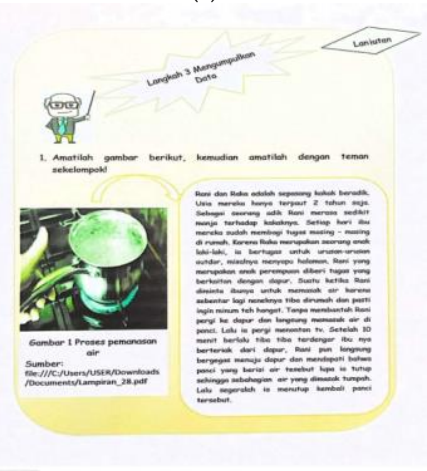

(e)

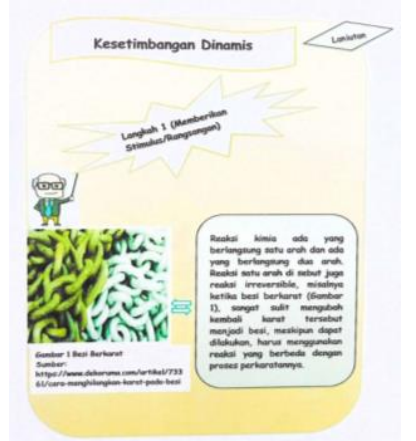

(d)

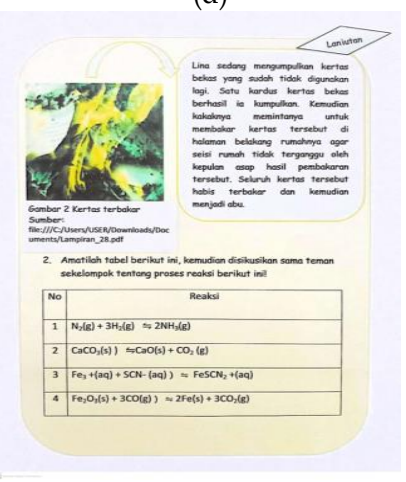

(f)
Figure 1. Student Worksheet Draft (a) cover, (b) instructions,

(c) Basic Competencies, (d) supporting information (stimulus), and (e) assignments (exercise)

\section{Initial draft trial}

At the initial draft trial stage, to ensure the quality of Discovery Learning-based Student Worksheets in improving students' critical thinking skills, it is necessary to carry out a validation process for material experts and media experts. The validity of the Student Worksheet can be seen from two things, namely the validity of the content (relevancy) and the validity of the construct (consistency). The validation of the Student Worksheets was carried out on three material expert validators so that this Student Worksheet was appropriate to be used as teaching material for research. The validation process consists of several aspects of the assessment including; completeness of the material, accuracy, timeliness, and fitness for purpose. The results of the expert's correction will be used as the basis for revising the Student Worksheet so that this Discovery Learningbased Student Worksheet is appropriate to use. The Discovery Learning-based Student Worksheet assessment can be feasible after an expert carries out the validation process. As for several revisions that must be corrected by the expert so that the Student Worksheet can be used, it can be seen in Table 1 .

Table 1. Revision of the design of the Student Worksheet during the validation process

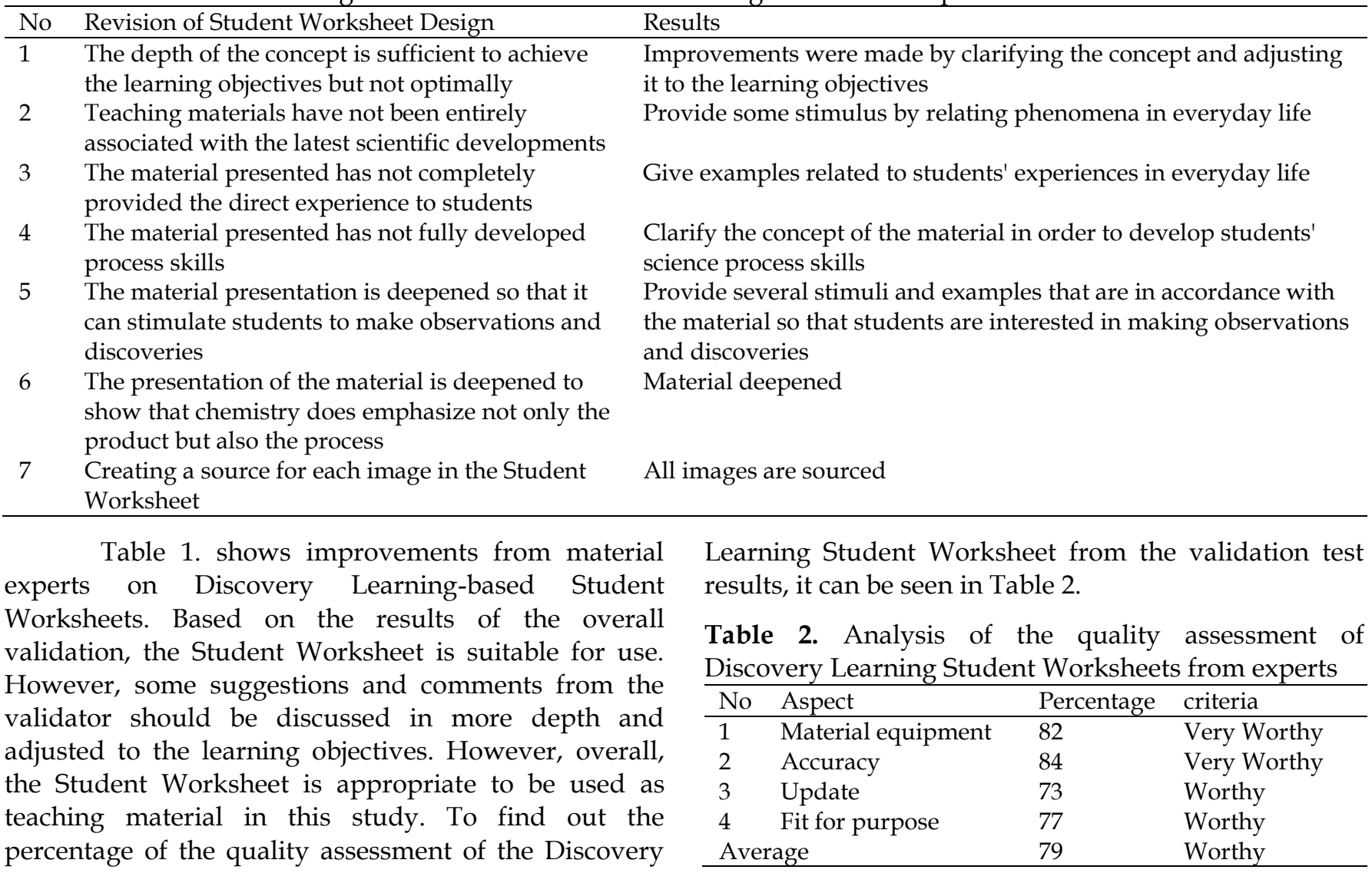


Table 2 shows the results of the validation assessment of the quality of teaching materials in the form of Discovery Learning Discovery Student Worksheets. Based on the results of the analysis of the quality assessment of Discovery Learning Student Worksheets from the validation test results obtained an average of $79 \%$ with a decent category. The results obtained prove that Discovery Learning Student Worksheets can be developed as teaching materials to improve students' critical thinking skills.

After knowing the results of the content validation on the Discovery Learning Student Worksheet, then to measure students' critical thinking skills through the application of the Discovery Learning Student Worksheet, the instrument used was a matter of Critical Thinking Skills. The material expert validation process is first carried out to determine the feasibility of the Critical Thinking Skills questions used in this study. Three chemists carried out the validation process. Based on the results of Aiken's analysis (Azwar, 2018), from the thirty questions, the overall Critical Thinking Skills question can be interpreted as a fairly high coefficient. In this case, it can be concluded that overall, the questions can be categorized as valid and good.

\section{Revise the initial product}

Based on the initial draft test results of the Discovery Learning-based Student Worksheet, there were several improvements from the expert validation test results. Several improvements to the Student Worksheet product after validation were carried out in accordance with the direction of material experts, including; deepening the material more clearly, linking the material with the concept of novelty, the material presented has been able to stimulate students, as well as the linkage of the material with phenomena in everyday life and using sources in each picture.

\section{Field trial I}

The first field trial was carried out after the product validation process for the Student Worksheet. The first trial activity was carried out from 15 to March 22, 2021. The field trial was carried out on a small sample of 60 Islam Al-Falah Senior High School class XII students.

In the field trial stage 1, they also distributed response questionnaires to the 60 students. The purpose of distributing this questionnaire is to determine student responses to the Discovery Learning Student Worksheet application, which was carried out in the field trial phase I. The results of the student response analysis in the first field trial can be seen in Table 3.

Table 3. Results of Student Response Analysis Field Trial 1

\begin{tabular}{|c|c|c|c|}
\hline No & Item & Average & Student Response \\
\hline 1 & Student worksheets use easy-to-understand language & 59.0 & Negative \\
\hline 2 & The Student Worksheet uses sentences that do not cause double meaning & 64.0 & Positive \\
\hline 3 & $\begin{array}{l}\text { The activity instructions in the Student Worksheet are clear, making it easier for me to } \\
\text { carry out all activities }\end{array}$ & 65.3 & Positive \\
\hline 4 & $\begin{array}{l}\text { The choice of font, size, and space used makes it easier for me to read the Student } \\
\text { Worksheet }\end{array}$ & 62.3 & Positive \\
\hline 5 & $\begin{array}{l}\text { At the beginning of learning using this student worksheet, there is something that } \\
\text { interests me }\end{array}$ & 57.0 & Negative \\
\hline 6 & The presentation style of this Student Worksheet is boring & 75.7 & Positive \\
\hline 7 & On every page, there are words or sentences that I don't understand & 66.0 & Positive \\
\hline 8 & In this lesson, I often state questions in the form of pictures, sketches, or diagrams & 81.0 & Very Positive \\
\hline 9 & $\begin{array}{l}\text { A variety of activities, assignments, practice questions, illustrations, and others help } \\
\text { me to develop my chemistry skills }\end{array}$ & 79.3 & Positive \\
\hline 10 & $\begin{array}{l}\text { When studying, I always re-examine the results of the work I get and make } \\
\text { conclusions according to the problem asked }\end{array}$ & 71.3 & Positive \\
\hline 11 & $\begin{array}{l}\text { From every activity in this Student Worksheet, I can conclude and take important ideas } \\
\text { about chemical equilibrium material }\end{array}$ & 54.3 & Negative \\
\hline 12 & $\begin{array}{l}\text { I can relate the contents of this Student Worksheet with things I have seen, done, or } \\
\text { thought about in my daily life. }\end{array}$ & 61.0 & Positive \\
\hline 13 & $\begin{array}{l}\text { I am able to make chemical models from problems in the form of descriptions and } \\
\text { story problems }\end{array}$ & 43.7 & Negative \\
\hline 14 & I can gain knowledge by following a series of activities in the student worksheets & 61.0 & Positive \\
\hline 15 & As I learn to use this Student Worksheet, I believe that I can study its contents well & 55.3 & Negative \\
\hline 16 & $\begin{array}{l}\text { After studying the chemical equilibrium material using this Student Worksheet, I } \\
\text { believe that I will succeed in the test }\end{array}$ & 61.7 & Positive \\
\hline 17 & The contents of this Student Worksheet are very useful for me & 59.0 & Negative \\
\hline
\end{tabular}




\begin{tabular}{|c|c|c|c|}
\hline No & Item & Average & Student Response \\
\hline 18 & There is no material in this Student Worksheet that I understand & 65.0 & Positive \\
\hline 19 & I like to learn chemistry, especially chemical equilibrium using this Student Worksheet & 62.3 & Negative \\
\hline 20 & Fill in this Student Worksheet according to my interests & 60.7 & Positive \\
\hline \multicolumn{2}{|c|}{ Overall Average } & 63.0 & Positive \\
\hline
\end{tabular}

Table 3 shows the results of the analysis of student responses to the Discovery Learning Student Worksheet test results on a small sample. Based on the results of the data analysis, we obtained an overall average score of 63.0, including the positive category. However, the results of the analysis of student responses per item are still in the negative category.

\section{Doing product revision}

Based on the results of field trial 1, on a small sample of 60 students, there are still some improvements to the Student Worksheet in accordance with the results of the student responses. Some improvements or revisions to the phase 1 field trials include: (1) Discovery Learning Student Worksheet language does not use easy-to-understand language; (2) Discovery Learning Student Worksheets are of no interest to students; (3) The activities in the Discovery Learning Student Worksheet are inconclusive, and important ideas are taken about chemical equilibrium material; (4) Students have not been able to make questions in the form of descriptions and story questions; (5) There are still students who have not been able to use the Discovery Learning Student Worksheet; (6) There are still some students who find the contents of the Discovery Learning Student Worksheet less useful. Based on the results of the students' responses, it is necessary to make improvements for field trials II.

\section{Field trial II}

The second field trial was carried out on 80 students of class XI at Islam Al-Falah Senior High School and IT Al-Fityan Senior High School. The purpose of testing a large sample is to determine the feasibility of the Discovery Learning Student Worksheet on the chemical equilibrium material. To find out the results of the analysis of students' answers to the application of the Discovery Learning Student Worksheet in the second field trial, it can be seen in Table 4.

Table 4. Results of Student Response Analysis Field Trial II

\begin{tabular}{|c|c|c|c|}
\hline No & Item & Average & Student Response \\
\hline 1 & Student activity sheets use language that is easy to understand & 84.3 & Very Positive \\
\hline 2 & The Student Worksheet uses sentences that do not cause double meaning & 90.5 & Very Positive \\
\hline 3 & $\begin{array}{l}\text { The activity instructions in the Student Worksheet are clear, making it easier for me } \\
\text { to carry out all activities }\end{array}$ & 84.8 & Very Positive \\
\hline 4 & $\begin{array}{l}\text { The choice of font, size and space used makes it easier for me to read the Student } \\
\text { Worksheet }\end{array}$ & 84.5 & Very Positive \\
\hline 5 & $\begin{array}{l}\text { At the beginning of learning using this student worksheet, there is something that } \\
\text { interests me }\end{array}$ & 86.8 & Very Positive \\
\hline 6 & The presentation style of this Student Worksheet is boring & 81.0 & Very Positive \\
\hline 7 & On every page, there are words or sentences that I don't understand & 94.3 & Very Positive \\
\hline 8 & In this lesson, I often state questions in the form of pictures, sketches, or diagrams & 91.8 & Very Positive \\
\hline 9 & $\begin{array}{l}\text { A variety of activities, assignments, practice questions, illustrations, and others help } \\
\text { me to develop my chemistry skills }\end{array}$ & 92.0 & Very Positive \\
\hline 10 & $\begin{array}{l}\text { When studying, I always re-examine the results of the work I get and make } \\
\text { conclusions according to the problem asked }\end{array}$ & 93.0 & Very Positive \\
\hline 11 & $\begin{array}{l}\text { From every activity in this Discovery Learning Student Worksheet, I can conclude } \\
\text { and take important ideas about chemical equilibrium material. }\end{array}$ & 93.5 & Very Positive \\
\hline 12 & $\begin{array}{l}\text { I can relate the contents of this Discovery Learning Student Worksheet to things I } \\
\text { have seen, done, or thought about in my daily life. }\end{array}$ & 94.0 & Very Positive \\
\hline 13 & $\begin{array}{l}\text { I am able to make chemical models from problems in the form of descriptions and } \\
\text { story problems }\end{array}$ & 95.8 & Very Positive \\
\hline 14 & I can gain knowledge by following a series of activities in the student worksheets & 94.3 & Very Positive \\
\hline 15 & $\begin{array}{l}\text { As I learn to use this Discovery Learning Student Worksheet, I believe that I can } \\
\text { study its contents well }\end{array}$ & 95.5 & Very Positive \\
\hline 16 & $\begin{array}{l}\text { After studying the chemical equilibrium material using this Discovery Learning } \\
\text { Student Worksheet, I believe that I will succeed in the test }\end{array}$ & 94.3 & Very Positive \\
\hline 17 & The contents of this Discovery Learning Student Worksheet are very useful for me & 95.8 & Very Positive \\
\hline 18 & There is no material in this Discovery Learning Student Worksheet that I understand & 93.8 & Very Positive \\
\hline 19 & I enjoy learning chemistry, especially chemical equilibrium using this Discovery & 94.8 & Very Positive \\
\hline
\end{tabular}




\begin{tabular}{llrr}
\hline No & Item & Average & Student Response \\
\hline $\begin{array}{l}\text { Learning Student Worksheet } \\
\text { The contents of this Discovery Learning Student Worksheet are according to my } \\
\text { interests }\end{array}$ & 95.5 & Very Positive \\
Overall Average & 91.5 & Very Positive \\
\hline
\end{tabular}

Table 5 shows the results of the student response analysis in the second field trial with a sample of 80 people. Based on the results of the data analysis, the average student overall obtained a score of 91.5 in the very positive category. This proves that the Discovery Learning Student Worksheet model is suitable for mass production.

\section{Revise the final product}

Based on the results of the field trial II on a large sample of 80 students, it can be concluded that the average student responded very positively to the implementation of the Discovery Learning Student Worksheet. This second field trial results prove that the development of the Discovery Learning Student Worksheet is suitable for continuing research without revising.

\section{Product dissemination}

Based on the validation test results on two validators at the material expert, it proved that the results of the validation of the content of the questions in each of the assessed aspects could be interpreted all the assessment items of the Discovery Learning Student Worksheet can be used to improve students' Critical Thinking Skills.

\section{Results of Analysis of Students' Critical Thinking Skills}

Critical thinking skills are an individual's competence in conceptualizing, analyzing, synthesizing, and evaluating to reach answers or conclusions (Changwong, 2018). This study's critical thinking skills were measured in five of the six indicators proposed by Focione (2015), including; interpretation, analysis, conclusion, evaluation, explanation, and self-regulation.

The improvement of students' critical thinking skills before and after applying the learning treatment can be analyzed using the N-gain equation. The results of the analysis of the increase in Critical Thinking Skills of students in the experimental class and control class in more detail can be seen in table 5 .

Table 5. Results of Analysis of Students' Critical Thinking Skills Improvement

\begin{tabular}{lllll}
\hline Classes & Pretest & Posttest & N-gain & Category \\
\hline Experiment & 51 & 78 & 0.54 & medium \\
Control & 50 & 65 & 0.30 & low \\
\hline
\end{tabular}

Table 5 shows the analysis results of increasing students' Critical Thinking Skills in the experimental and control classes. Based on the results of the analysis, it was obtained that the average increase in students' Critical Thinking Skills after applying the Discovery Learning Student Worksheet was higher than in the control class using conventional Student Worksheets. In line with research conducted by Syamsu (2020), which states that learning activities through Discovery Learning Student Worksheets are able to recognize and distinguish the causes and effects of a complex scenario, analyze incoming information, identify patterns or relationships, and identify or formulate questions. Hilmi et al. (2017) \& Masril et al. (2019) also say that the Discovery Learning learning model can help students build knowledge independently through various activities based on existing prior knowledge. Hypothesis testing was conducted to determine the average difference between students' Critical Thinking Skills in the experimental and control classes. Hypothesis testing was used in the form of an independent sample $t$-test. The prerequisites for conducting hypothesis testing consist of; normality test and homogeneity test. Normality test aims to determine whether the data used is normally distributed or not. Normality test used in the form of Kolmogorov-Smirnov.

The results of testing the hypothesis to determine the average difference in students' Critical Thinking Skills before and after applying the experimental class and control class learning treatment can be seen in Table 6 below.

Table 6. Results of Hypothesis Testing Analysis

\begin{tabular}{|c|c|c|c|c|}
\hline No & Classes & Normality* & Homogenity** & Significance ${ }^{* * *}$ \\
\hline $\begin{array}{l}1 \\
2\end{array}$ & $\begin{array}{l}\text { Experiment } \\
\text { Control }\end{array}$ & $\begin{aligned} 0.200>0.05 \text { (normally distributed) } \\
0.200>0.05 \text { (normally distributed) }\end{aligned}$ & $0.648>0.05$ homogeneous & $0.000<0.05$ (significan-tly different) \\
\hline \multicolumn{5}{|c|}{ Keterangan: } \\
\hline *) & \multicolumn{4}{|c|}{$=$ Smirnov (normally distributed, sig value $>0.05, \alpha=0.05$ ) } \\
\hline **) & \multicolumn{4}{|c|}{$=$ Test of Homogeneity of Varians (homogeneous, sig value $>0.05, \alpha=0.05$ ) } \\
\hline$* * *)$ & \multicolumn{4}{|c|}{$=$ Independent Sample t Test (signifikan, sig $<0.05, \alpha=0.05$ ) } \\
\hline
\end{tabular}


The independent-sample t-test results in the experimental class and control class obtained the value of Sig. (2-tailed) 0.000. If the value of Sig. (2-tailed) < 0.05 , then there is a significant difference between students' Critical Thinking Skills in the experimental and control classes. This proves that there is a difference in the average critical thinking skills of students after applying the Discovery Learning Student Worksheet in the experimental class compared to the conventional Student Worksheet in the control class. This is in accordance with research conducted by Izzatunnisa et al. (2019) that discovery learning-based Student Worksheets are best applied in the chemistry learning process because the Student Worksheets have been integrated with the stages of discovery learning and are able to increase student participation during the learning process learning, train and develop students' critical and creative thinking, train and develop students' procedural knowledge, and can shape and develop students' scientific literacy skills.

To find out the average increase in the Critical Thinking Skills of the indicator students in the experimental and control class, it can be seen in Figure 2 below.

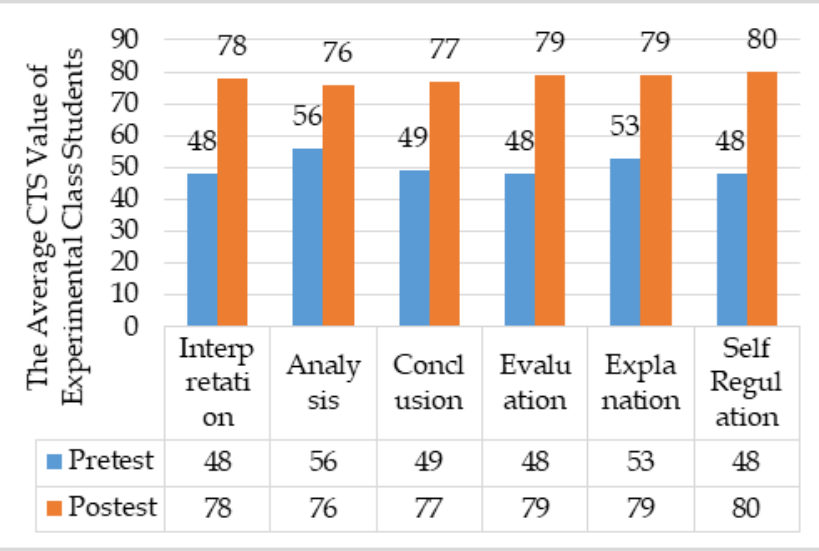

Figure 2. Results of the Analysis of the Average Critical Thinking Skills of the Experimental Class indicator students Experimental class indicators

Figure 2 shows the results of the analysis of the Critical Thinking Skills of the indicator students in the experimental class. The analysis results showed that after implementing learning activities using the Discovery Learning Student Worksheet, there was an increase in students' Critical Thinking Skills in each indicator compared to before implementing it. This proves that the Discovery Learning Student Worksheet is able to improve students' Critical Thinking Skills. Similar research results were stated by Rahman et al. (2021) that Discovery Learning is learning that emphasizes critical thinking processes during learning so that their thinking abilities can be used optimal because by applying Discovery Learning learning, students are required to be active and find their own answers to a problem so that students' thinking skills can be used well.

Similar research results: Hasanah et al. (2018) that the implementation of Discovery Learning learning in classroom learning is in the high category, shown in the Discovery Learning model syntax, which can be trained in elaboration thinking skills. Jannah et al. (2021) also said that the Discovery Learning model could improve reasoning, think freely, and have skills in finding a concept. Furthermore, to find out the average results of the indicator students' Critical Thinking Skills can be seen in Figure 3.

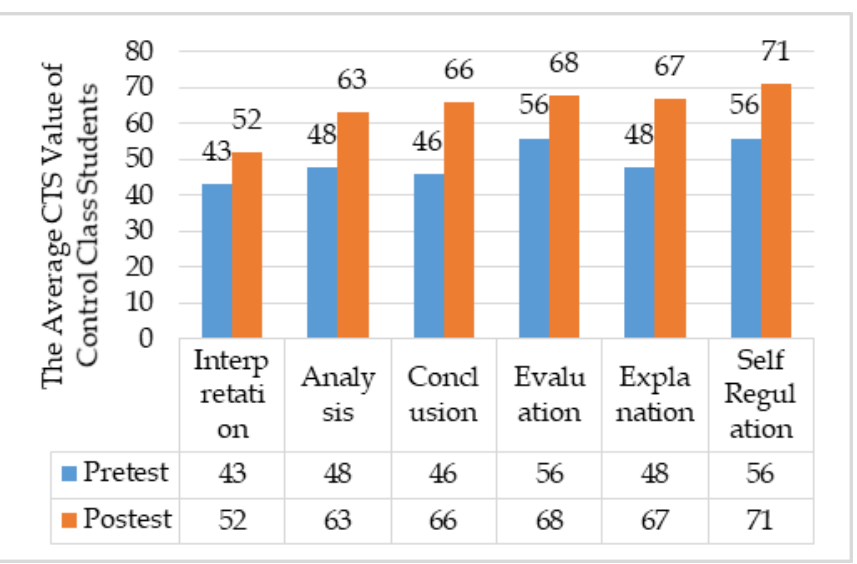

Figure 3. The results of the analysis of the average critical thinking skills of students in the control class indicator

Figure 3 shows the results of the analysis of the average Critical Thinking Skills of the indicator students in the control class. Based on the results of the analysis of the Critical Thinking Skills of the students in the control class, it was proven that the average of the students' Critical Thinking Skills was an indicator lower than that of the experimental class. This proves that the Discovery Learning Student Worksheet is better applied than the conventional Student Worksheet. After knowing the average results of the pretest and posttest Critical Thinking Skills indicators in the experimental class and control class, it can also be seen the results of increasing students' Critical Thinking Skills through the analysis of the $\mathrm{N}$-gain equation. The results of the $\mathrm{N}$-gain analysis of the Critical Thinking Skills indicator, in more detail, can be seen in table 7. 
Table 7. Results of Analysis of Students' Critical Thinking Skills

\begin{tabular}{lllllll}
\hline No & Question Number & Indicator & $N$-gain Experiment & Category & $N$-gain Control & Category \\
\hline 1 & CTS $1: 1,2,3$ & Interpre-tation & 0.58 & medium & 0.16 & low \\
2 & CTS $2: 4,5,6$ & Analisys & 0.45 & medium & 0.29 & low \\
3 & CTS $3: 7,8,9,10$ & Conclu-sion & 0.55 & medium & 0.37 & medium \\
4 & CTS $4: 11,12,13,14$ & Evalua-tion & 0.60 & medium & 0.27 & medium \\
5 & CTS 5: 15,16 & Explana-tion & 0.55 & medium & 0.37 & medium \\
6 & CTS 6: $17,18,19,20$ & Self-regulation & 0.62 & medium & 0.34 & medium \\
\hline
\end{tabular}

Based on table 7, the average N-gain of students' Critical Thinking Skills through the Discovery Learning Student Worksheet application on each indicator is included in the medium category. In comparison, the control class is included in the low and medium categories. The results obtained prove that the increase in Critical Thinking Skills of students in the experimental class is higher than in the control class. This is because in accordance with the opinion expressed by Andayani (2020) that the Discovery Learning model is a learning activity that emphasizes the ability of students to actively and independently prove hypotheses. Khasani et al. (2019) say that students' Critical Thinking Skills can be formed due to the construction of the student learning process, which is carried out based on problem-based learning and discovery.

\section{Conclusion}

Based on the results of previous research, it can be concluded that the quality of the Discovery Learning Student Worksheet can improve students' critical thinking skills on chemical equilibrium materials. This is evidenced by the results of the quality assessment of the Discovery Learning Student Worksheet from validation results obtained an average of $79 \%$ with eligible categories. The analysis of students' critical thinking skills proves a difference in the average critical thinking skills of students before and after applying the Discovery Learning Student Worksheet on chemical equilibrium material with a Sig value. (2-tailed) $<0.05$. The results obtained prove that the use of Discovery Learning Student Worksheets is better than conventional Student Worksheets in improving students' Critical Thinking Skills.

\section{Acknowledgments}

Thank you to the leadership and teaching staff at AlFalah Islamic Senior High School Aceh Besar and AlFitiyan Aceh Besar Senior High School who have provided service facilities during the research and thank you to the supervisor who has guided in completing this article.

\section{References}

Amijaya, L. S., Ramdani, A. \& Merta, W. (2018). Pengaruhmodel pembelajaran inkuiri terbimbing terhadap hasil belajar dan kemampuan berpikir kritis peserta didik. Jurnal Pijar MIPA. 2(13): 9499. doi:http://dx.doi.org/10.29303/jpm.v13i2.46 [Indonesian]

Andayani, S. (2020). Development of Learning Tools Based on Discovery Learning Models Combined with Cognitive Conflict Approaches to Improve Students' Critical Thinking Ability. Jurnal Penelitian Pendidikan IPA, 6(2), 238-242. doi:https://doi.org/10.29303/jppipa.v6i2.438

Arianti, D., \& Meutiawati, I. (2020). Pengembangan Lembar Kerja Peserta Didik (LKPD) berbasis discovery learning pada materi kalor di SMP. Jurnal Phi, 1(3): 13-19. doi: http://dx.doi.org/10.22373/p-jpft.v1i1.6477 [Indonesian]

Azwar, S. (2018). Reliabilitas dan Validitas. Yogyakarta: Pustaka Pelajar. [Indonesian]

Borg, W.R., \& Gall, M.D. (1989). Edicational Research: An Introductional ( $5^{\text {the }}$ ). New York: Longman.

Changwong, K., Sukkamart, A. \& Sisan, B. (2018). Critical thinking skill develop: Anlysis of a new learning management model for Thai high school. Journal of International Studies. 2(11): 37-4 doi: http://dx.doi.org/10.14254/20718330.2018/11-2/3

Depdiknas. (2006). Pedoman Memilih dan Menyusun Bahan Ajar. Retrieved from: (http://www.scribd.com/doc/26566848/Pedom an-Memilih-Dan-Menyusun-Bahan-Ajar [Indonesian]

Diani, R.D., Nurhayati., \& Suhendi, D. (2019). Pengembangan lembar kerja peserta didik (LKPD) menulis cerpen berbasis aplikasi android. BASASTRA Jurnal Bahasa, Sastra, dan Pengajarannya, 7(2):1-3. doi: https://doi.org/10.20961/basastra.v7i2.37800 [Indonesian]

Donuk, D. (2016). Revisiting Language Learning Through the Self: Discovery Learning in the 21st Century. Turkish Online Journal of English 
Language Teaching, 1, 66-74. https://doi.org/10.32959/tojelt.229319

Facione, P. A. (2015). Critical thinking: what it is and why it counts. California: Measured Reasons and the Californias Acedemic Press.

Fadila, N., \& Taufik, F. (2020). Penerapan model discovery learning dalam pembelajaran tematik terpadu di kelas IV sekolah dasar: studi literature. Jurnal Inovasi Pembelajaran SD, 8(9): 1130.

Retrieved from: http://ejournal.unp.ac.id/students/index.php/p gsd/article/view/10216 [Indonesian]

Farid, M. Faradiyah, A.R. Maghfira, A., Lestari, A.P. \& Tullah, H. (2018). Pengaruh media simulasi PHET menggunakan model discovery learning terhadap hasil belajar fisika peserta didik. Jurnal Nalar Pendidikan, 2(6):105-112. doi:https:// doi.org/10.2 6858/jnp.v6i2.7085 [Indonesian]

Hasanah, M., Rudibyani, B.R., \& Tania, L. (2018). Penerapan discovery learning untuk meningkatkan keterampilan berpikir elaborasi pada materi larutan penyangga. Jurnal Pendidikan dan Pembelajaran Kimia, 7(1):142-153. Retrieved from: http://jurnal.fkip.unila.ac.id/in dex.php/JPK/article/view/13984 [Indonesian]

Hilmi, N., Harjono, A., \& Soeprianto. (2017). Pengaruh Model Pembelajaran Discovery dengan Pendekatan Saintifik dan Keterampilan Proses Terhadap Hasil Belajar Fisika Peserta Didik. Jurnal Penelitian Pendidikan IPA (JPIPA), 3(2):1-7. Doi:

doi:

https://doi.org/10.29303/jppipa.v3i2.85 [Indonesian]

Izzatunnnisa, I., Andayani, Y., \& Hakim, A. 2019. Pengembangan IKPD berbasis pembelajaran penemuan untuk meningkatkan kemampuan literasi sains peserta didik pada materi kimia SMA. J. Pijar MIPA, 14(2):49-54. doi: http://dx.doi.org/10.29303/jpm.v14i2.1240 [Indonesian]

Jannah, M., Khaldun, I., \& Safrida, S. (2020). Application of Virtual Laboratory assisted Discovery Learning Model to Improve Science Process Skills and Learning Outcomes in Circulatory System Material. Jurnal Penelitian Pendidikan IPA, 7(1), 3440. doi:https://doi.org/10.29303/jppipa.v7i1.470

Khasani, R., Ridho, S., \& Subali, B. (2019). Identifikasi Kemampuan Berpikir Kritis Siswa SMP Pada Materi Hukum Newton. Jurnal Penelitian Pendidikan IPA, 5(2), 165-169. doi:https:// doi.org/10.29303/ippipa.v5i2.192 [Indonesian]

Lestari, L., Kurniawan, E., \& Fatmaryanti, S. (2019). Pengembangan lembar kegiatan peserta didik berbasis Thinking Actively in Social Context
(TASC) untuk meningkatkan kemampuan mencipta pada peserta didik SMA. Jurnal Riset Dan Kajian Pendidikan Fisika, 6(1), 10 - 16. doi:http://dx.doi.org/10.12928/jrkpf.v6i1.11364 [Indonesian]

Masril, M., Hidayati, H., \& Darvina, Y. (2018). Penerapan Discovery Learning Berbantuan Virtual Laboratory Untuk Meningkatkan Kompetensi Fisika Siswa SMA. Jurnal Penelitian Pendidikan IPA, doi:https://doi.org/10.29303/jppipa.v5i1.160 [Indonesian]

Nugrahaeni, A., Redhana, I., \& Kartawan, I. (2017). Penerapan Model Pembelajaran Discovery Learning Untuk Meningkatkan Kemampuan Berpikir Kritis Dan Hasil Belajar Kimia. Jurnal Pendidikan Kimia Indonesia, 1(1), 23-29. doi:http://dx.doi.org/10.23887/jpk.v1i1.12808 [Indonesian]

Puspendik. 2019. Laporan Hasil Ujian Nasional SMA/MA Tahun Pelajaran 2018/2019 Jakarta: Balitbang Kemdikbud. Balitbang Kemendikbud, Retrieved from:

https://hasilun.puspendik.kemdikbud.go.id/...\& !1!\& [Indonesian]

Putra, A., Syarifuddin, H., \& Zulfah, Z. (2018). Validitas Lembar Kerja Peserta Didik Berbasis Penemuan Terbimbing dalam Upaya Meningkatkan Pemahaman Konsep dan Kemampuan Penalaran Matematis. Edumatika : Jurnal Riset Pendidikan Matematika, 1(2), 56-62. https://doi.org/10.32939/ejrpm.v1i2.302 [Indonesian]

Qurniati, D., Andayani, Y., \& Muntari. (2015). Peningkatan keterampilan berpikir kritis melalui model pembelajaran discovery learning. Jurnal Penelitian Pendidikan IPA (JPPIPA), 1(2):58-69. doi: https://doi.org/10.29303/ippipa.v1i2.20 [Indonesian]

Rahman, L.L., Rusyana, A., \& Yulisma, L. (2021). pengaruh model pembelajaran discovery learning berbasis LKS tipe word square terhadap keterampilan berpikir kritis siswa. J-KIP (Jurnal Keguruan dan Ilmu Pendidikan), 2(1):33-38. Retrieved from: https://jurnal.unigal.ac.id/index.php/J$\mathrm{KIP} /$ article/view/4814 [Indonesian]

Rahman, M. (2017). Using Discovery Learning to Encourage Creative Thinking. International Journal of Social Sciences and Educational Studies, 4, 98-103. https://doi.org/10.23918/ijsses.v4i2sip98 Syamsu, D.F. (2020). Pengembangan lembar kerja peserta didik berorientasi pembelajaran discovery learning untuk meningkatkan keterampilan berpikir kritis siswa. Jurnal Genta 
Mulia, 11(1): 65-79. Retrieved from:

https:// ejournal.stkipbbm.ac.id/index.php/gm/ article/view/394 [Indonesian]

Taufik, A., Rahayuningsari, N., \& Dadi, O. (2021). Pengembangan LKS Berbasis Model Discovery Learning dan Kemampuan Berpikir Kritis Matematika. Musamus Journal of Mathematics Education, 3(1), 38-47. https://doi.org/10.35724/mjme.v3i1.3459 [Indonesian]

Zammiluni, Z., Ulianas, A., \& Mawardi, M. (2018). Development of Guided Inquiry Based Work Sheet with Class and Laboratory Activity on Chemical Bonding Topic in Senior High School. International Journal of Chemistry Education Research, 2(2), 60-66. doi:https://doi.org/10.20885/ijcer.vol2.iss2.art1 